\title{
Growth and Yield of Different Varieties of Chickpea (Cicer arietinum L.) as Influenced by the Phosphorus Nutrition under Rainfed Conditions on Vertisols
}

\author{
S. Neenu*, K. Ramesh, S. Ramana, A. K. Biswas and A. Subba Rao
}

Indian Institute of Soil Science, Nabi bagh, Bhopal, Madhya Pradesh (462 038), India

\section{Article History}

Manuscript No. cn317

Received in $28^{\text {th }}$ January, 2013

Received in revised form $15^{\text {th }}$ December, 2013

Accepted in final form $25^{\text {th }}$ February, 2014

\section{Correspondence to}

*E-mail: neenusibi@gmail.com

\section{Keywords}

chickpea, phosphorus, yield, vertisols, variety

\begin{abstract}
A field experiment was carried out in Indian Institute of Soil Science, Bhopal during the rabi season 2011-12 to study the effect of different doses of phosphorus on the growth and yield of different varieties of chickpea (Cicer arietinum L.) under rainfed conditions in vertisols. The experiment was laid out in a Split plot design with three replications. There were four phosphorus levels viz., 0, 30, 60 and $90 \mathrm{~kg} \mathrm{P}_{2} \mathrm{O}_{5}$ ha $^{-1}$ and four varieties of chickpea viz., JG 16, JG 11, JG 315 and JG 218. Barring JG 11, application of phosphorus from 0 to $60 \mathrm{~kg} \mathrm{ha}^{-1}$ resulted in a linear increase in yield and yield attributing characters in rest of the varieties. Although there was no significant difference in seed yield among the varieties, application of either 60 or $90 \mathrm{~kg} \mathrm{P}_{2} \mathrm{O}_{5}$ $\mathrm{ha}^{-1}$ produced significantly higher seed yield over other doses of $\mathrm{P}$. The application of phosphorus above $60 \mathrm{~kg} \mathrm{ha}^{-1}$ has significantly increased the grain phosphorus content in all the four varieties but the interaction effect was not significant. A significant increase of grain phosphorus uptake with phosphorus nutrition was also observed in all the varieties.
\end{abstract}

\section{Introduction}

Chickpea (Cicer arietinum L.) is one of the most important grain legumes and belongs to the family Leguminosae. It is a drought tolerant leguminous crop used in various foods in several developing countries including India as a source of highly digestible (70-90\%) dietary protein. The yield of chickpea was found to be less in farmer's field mainly due to the inappropriate production practices and biotic/abiotic stresses. It is reported that resistance to biotic and abiotic stress is negatively related to yield (Maiti, 2012). Pulses require phosphorus for growth and nitrogen fixation. Since it helps for better root development, phosphorus application is a must for the crops grown under rainfed conditions. Recent researches revealed that there is a good response of chickpea to phosphorus fertilizer (Mehar Singh et al., 2000). If the phosphate availability from the soil is limited, the growth and nitrogen fixation are affected (Prasad and Sanoria, 1981). Influence of phosphorus on root growth and nodule nitrogen fixation which affects the nutrients uptake is well known.

Low soil fertility, particularly phosphorus (P) deficiency, is one of the major constraints to increasing chickpea productivity (Srinivasarao et al., 2003). The chickpea breeding program in India has not yet considered the varietal variation in phosphorus (P) efficiency of chickpea varieties. In general, phosphorus application to chickpea is at sub-optimum levels, efficient P-utilizing varieties will perform better than others under P-deficient conditions. The most common varieties of chickpea used in Central India were selected to study their response to different levels of phosphorus. Since phosphorus is exceptionally important for the pulse crop especially chickpea and the behaviour of phosphorus in soil varies with the soil conditions, this study is important for the efficient use of phosphorus, a costly input in agriculture.

\section{Materials and Methods}

A field experiment was conducted to study the effect of different phosphorus levels viz., 0, 30, 60 and $90 \mathrm{~kg} \mathrm{ha}^{-1}$ on growth and yield of four varieties of chickpea in vertisols. The experimental soil contained $0.65 \%$ organic carbon, $264.9 \mathrm{~kg}$ $\mathrm{ha}^{-1}$ nitrogen, $13.6 \mathrm{~kg} \mathrm{ha}^{-1}$ available phosphorus and $640.8 \mathrm{~kg}$ $\mathrm{ha}^{-1}$ available potassium with $\mathrm{pH}$ 8.42. Experiment was laid out in a split plot design with three replications and the net plot size was $3.0 \times 5.0 \mathrm{~m}^{2}$. Seedbed was prepared by $2-3$ times ploughing followed by plankings. There were four varieties of chickpea (JG 16, JG 11, JG 315 and JG 218 as $\mathrm{V}_{1}, \mathrm{~V}_{2}, \mathrm{~V}_{3}$ and $\mathrm{V}_{4}$, respectively). The breeder seeds of these different varieties were collected from the respective research stations. 
The sowing was done manually with seed rate of $80 \mathrm{~kg} \mathrm{ha}^{-1}$ with a row to row distance of $45 \mathrm{~cm}$.

A starter dose of N@20 kg ha-1 and K@20 kg ha-1 was applied at sowing in the form of Urea and Muriate of Potash. Zinc in the form of Zinc Sulphate (21\% Zn and 18\% S) @ 20 $\mathrm{kg} \mathrm{ha}^{-1}$ to supply $5 \mathrm{~kg}$ Zinc was also applied. Phosphorus was applied at four levels $\left(\mathrm{P}_{1}: 0 \mathrm{~kg}, \mathrm{P}_{2}: 30 \mathrm{~kg}, \mathrm{P}_{3}: 60 \mathrm{~kg}\right.$ and $\mathrm{P}_{4}$ : $90 \mathrm{~kg} \mathrm{P}_{2} \mathrm{O}_{5} \mathrm{ha}^{-1}$ ) supplied through single super phosphate (16 $\mathrm{kg} \mathrm{P}_{2} \mathrm{O}_{5}$ ). Thinning was done at 15 days after germination to maintain a plant to plant distance of $10 \mathrm{~cm}$ and optimum plant population. Hoeing was done thrice to keep the crop weed free. No irrigation was given as the crop was raised as rainfed crop. Different varieties were harvested on different dates according to their maturity (Table 1).

Five plants were selected at random from each net plot for recording observation. Days to $50 \%$ flowering was recorded by counting the total number of days required for $50 \%$ of the total population to reach flowering stage, days to physiological maturity was recorded by counting number of days required the entire plants to reach yellow and dry stage, number of pods plant ${ }^{-1}$ was recorded by counting the total number of pods plant ${ }^{-1}$, seed yield by taking the total yield ha ${ }^{-1}$, seed index by weighing the 100 seeds from each treatment. Harvest index was calculated by dividing the seed yield with that of biological yield (seed + straw). Phosphorus content in the grain was analysed by vanadomolybdophosphoric yellow colour method (Jackson, 1973) and phosphorus uptake by grain was calculated by dividing the product of grain dry weight in $\mathrm{kg}$ $\mathrm{ha}^{-1}$ and grain phosphorus concentration by 100 .

\section{Results and Discussion}

\subsection{Seed yield and harvest index}

Although the varieties were indifferent for seed yield, phosphorus doses were found to influence the productivity significantly. The varietal interaction with phosphorus doses remained insignificant (Table 2). Even though there was no significant difference in seed yield among the varieties, application of either 60 or $90 \mathrm{~kg} \mathrm{P}_{2} \mathrm{O}_{5}$ ha $^{-1}$ were on par and produced significantly higher seed yield over other doses of $\mathrm{P}$.
Similar results were reported by Singh and Singh (2012). The plausible reason for increase in seed yield under either 60 or 90 $\mathrm{kg} \mathrm{ha}^{-1}$ could be that phosphorus is essential for cell division, development of root nodules and stimulation of nitrogen fixation (Marschner, 1995) which might have enhanced the yield. Phosphorus is also reported to enhance root development (Jones, 1982). Maximum (19.99 $\mathrm{q} \mathrm{ha}^{-1}$ ) and minimum (17.14 $\mathrm{q} \mathrm{ha}^{-1}$ ) seed productivity were registered for $\mathrm{V}_{2}(\mathrm{JG} 11)$ and $\mathrm{V}_{4}$ (JG 218) respectively. The results corroborate the findings of Borgohain and Agarwal (1986) and Tomar et al. (1993). Besides, there was an improvement in the number of pods plant $^{-1}$ as evident from Table 4. An increase in fertility level resulted in significant increase in yield of Linseed was reported by Meena et al. (2011). Similar results were obtained by Patil et al. (2002). The reduction in yield for the variety JG 16 at 90 $\mathrm{kg} \mathrm{P}_{2} \mathrm{O}_{5} \mathrm{ha}^{-1}$ might be due to some genotype related barriers. This is in conformity with the findings of Idris et al. (1989). Notwithstanding to this fact, harvest index remained unaffected (Table 3). Similar findings were reported by Khorgamy and Farnia (2009). In chickpea, changes in crop growth rate accounted for $47 \%$ of the variation in grain yield was reported by Williams and Saxena (1991). Usually varieties with longer growth duration produce more yield than the varieties with shorter growth duration. Hence daily productivity may be a better criterion for comparing varietal performance (Islam et al., 2010).

\subsection{Day to $50 \%$ flowering and physiological maturity}

Significant differences in days to $50 \%$ flowering and physiological maturity were observed for both phosphorus doses as well as varieties (Table 3). Shorter the duration, higher was the seed yield (Table 2). Those varieties with a short life span would reach flowering and maturity within short period as compared to long duration varieties. In the present study also, the variety $\mathrm{V}_{2}$ (JG 11) took significantly lesser time for attaining $50 \%$ flowering as well as physiological maturity whereas the variety $\mathrm{V}_{3}$ (JG 315) took longer time for both $50 \%$ flowering and physiological maturity. However, $\mathrm{V}_{1}$ (JG 16) was on par with $\mathrm{V}_{3}$ (JG 315) for physiological maturity. It is to be noted that there was an inverse relationship between duration

Table 1: Varietal characters used in the study

\begin{tabular}{|c|c|c|c|c|}
\hline$\underline{\text { Character }}$ & $\underline{\mathrm{JG} 16}\left(\mathrm{~V}_{1}\right)$ & $\mathrm{JG} 11\left(\mathrm{~V}_{2}\right)$ & $\underline{\mathrm{JG}} 315\left(\mathrm{~V}_{3}\right)$ & $\underline{\mathrm{JG}} 218\left(\mathrm{~V}_{\mathrm{t}}\right)$ \\
\hline Duration & 113 & $95-100$ & $110-130$ & $115-120$ \\
\hline Average yield $\left(\mathrm{q} \mathrm{ha}^{-1}\right)$ & $19-20$ & $15-17$ & $20-25$ & $18-20$ \\
\hline Growth habit & $\begin{array}{l}\text { Semi-spreading plant with } \\
\text { profused branching and } \\
\text { dark green foliage }\end{array}$ & Semi-spreading & $\begin{array}{l}\text { Erect with dark } \\
\text { green foliage }\end{array}$ & $\begin{array}{l}\text { Semi-erect, branching } \\
\text { from main stem }\end{array}$ \\
\hline Flower colour & Dark pink & Dark pink & Light pink & Medium sized pink colour \\
\hline 1000 seed weight & 220 & $225-240$ & $160-200$ & 180 \\
\hline
\end{tabular}


and seed yield as variety $\mathrm{V}_{2}$ (JG 11) matured early irrespective of the phosphorus dose and had recorded higher yield than others. This variation in days to flowering and maturity was the direct reflection of the duration of the varieties as evident from Table 1. However, better phosphorus nutrition favoured early flowering and maturity. This corroborates the opinion of Chauhan et al. (1992) reporting that phosphorus deficiency reduced the crop growth, delayed flowering and maturity in pigeon pea.

\subsection{Number of pods plant ${ }^{-1}$ and seed index}

It is evident that number of pods plant ${ }^{-1}$ and seed index differed significantly due to different varieties and phosphorus doses (Table 4). A direct relationship between number of pods plant ${ }^{-1}$ with seed yield was also noticed (Table 2 ). The possible reason might be the improvement in number of pods plant ${ }^{-1}$ due to sufficient phosphorus supply. Similar results were reported by Dixit et al. (1993). The variety $\mathrm{V}_{2}$ (JG 11) recorded significantly higher number of pods plant ${ }^{-1}(41.75)$ followed by $\mathrm{V}_{3}$ (JG 315). Significantly lower number of pods plant ${ }^{-1}$ were produced by $\mathrm{V}_{1}$ (JG 16) (33.25) and $\mathrm{V}_{4}$ (JG 218) (33.58) and were on par. In the case of phosphorus doses, the $\mathrm{P}_{4}(90$ $\mathrm{kg} \mathrm{P}_{2} \mathrm{O}_{5}$ ha $^{-1}$ ) treatment recorded significantly higher number of pods over other doses and control. The results indicated the significance of phosphorus doses on the production of number of pods plant ${ }^{-1}$ at each successive increment in phosphorus dose. The combination of $\mathrm{V}_{2}$ (JG 11) along with $90 \mathrm{~kg} \mathrm{P}_{2} \mathrm{O}_{5}$ $\mathrm{ha}^{-1}$ significantly superior over other comibtaions. This was followed by $\mathrm{V}_{3}$ (JG 315) at a phosphorus dose of $60 \mathrm{~kg} \mathrm{ha}^{-1}$. The more number of pods plant ${ }^{-1}$ in phosphorus treated plants might be due to the improvement in reproductive potential of the plants.

Seed index was significantly different between varieties and phosphorus treatment but the interaction remained unaffected. Significantly higher seed index was recorded by variety $\mathrm{V}_{2}$ (JG 11) and $\mathrm{V}_{4}$ (JG 218) and were statistically on par (Table 4). The variety $V_{2}$ (JG 11) recorded the significantly higher seed index (18.04) due to its boldness of seeds, however was on par with $\mathrm{V}_{4}$ (JG 218). It was followed by $\mathrm{V}_{1}$ (JG 16) with a seed index of $14.48 \mathrm{~g}$ and the lowest value was recorded by

Table 2: Effect of phosphorus levels on seed yield and harvest index

\begin{tabular}{|c|c|c|c|c|c|c|c|c|c|c|}
\hline \multirow[t]{3}{*}{ Variety } & \multicolumn{5}{|c|}{ Seed yield $\left(q\right.$ ha $\left.^{-1}\right)$} & \multicolumn{5}{|c|}{ Harvest index } \\
\hline & \multicolumn{10}{|c|}{ Phosphorus levels $\left(\mathrm{kg} \mathrm{ha}^{-1}\right)$} \\
\hline & 0 & 30 & 60 & 90 & Mean & 0 & 30 & 60 & 90 & Mean \\
\hline JG 16 & 16.47 & 17.77 & 20.87 & 20.53 & 18.91 & 0.49 & 0.50 & 0.52 & 0.53 & 0.51 \\
\hline JG 11 & 18.13 & 19.33 & 19.43 & 23.07 & 19.99 & 0.53 & 0.53 & 0.53 & 0.55 & 0.53 \\
\hline JG 315 & 13.87 & 16.07 & 19.90 & 20.13 & 17.49 & 0.46 & 0.46 & 0.49 & 0.49 & 0.48 \\
\hline JG 218 & 15.77 & 16.40 & 17.97 & 18.43 & 17.14 & 0.46 & 0.47 & 0.48 & 0.49 & 0.48 \\
\hline Mean & 16.06 & 17.42 & 19.52 & 20.54 & & 0.49 & 0.49 & 0.51 & 0.52 & \\
\hline Source & $\mathrm{SEm} \pm$ & $\mathrm{CD}(p=0.05)$ & & & & $\mathrm{SEm} \pm$ & $\mathrm{CD}(p=0.05)$ & & & \\
\hline Variety (V) & 0.86 & NA & & & & 0.025 & NA & & & \\
\hline P level (P) & 0.57 & 1.67 & & & & 0.025 & NA & & & \\
\hline $\mathrm{V} \times \mathrm{P}$ & 1.72 & NA & & & & 0.05 & NA & & & \\
\hline
\end{tabular}

Table 3: Effect of phosphorus levels on $50 \%$ flowering and physiological maturity

\begin{tabular}{|c|c|c|c|c|c|c|c|c|c|c|}
\hline \multirow[t]{3}{*}{ Variety } & \multicolumn{5}{|c|}{$50 \%$ flowering (days) } & \multicolumn{5}{|c|}{ Physiological maturity (days) } \\
\hline & \multicolumn{10}{|c|}{ Phosphorus levels $\left(\mathrm{kg} \mathrm{ha}^{-1}\right)$} \\
\hline & 0 & 30 & 60 & 90 & Mean & 0 & 30 & 60 & 90 & Mean \\
\hline JG 16 & 55.33 & 56.67 & 54.67 & 57.67 & 56.08 & 88.33 & 85.67 & 87.33 & 87.33 & 87.17 \\
\hline JG 11 & 49.00 & 49.00 & 49.00 & 49.00 & 49.00 & 84.33 & 84.33 & 84.33 & 82.67 & 83.92 \\
\hline JG 315 & 57.33 & 56.67 & 56.67 & 58.00 & 57.17 & 86.67 & 89.33 & 87.00 & 86.67 & 87.42 \\
\hline JG 218 & 54.00 & 54.00 & 54.00 & 54.00 & 54.00 & 86.67 & 88.67 & 85.33 & 83.67 & 86.08 \\
\hline Mean & 53.92 & 54.08 & 53.58 & 54.67 & & 86.50 & 87.00 & 86.00 & 85.08 & \\
\hline Source & $\mathrm{SEm} \pm$ & $\mathrm{CD}(p=0.05)$ & & & & $\mathrm{SEm} \pm$ & $\mathrm{CD}(p=0.05)$ & & & \\
\hline Variety $(\mathrm{V})$ & 0.09 & 0.26 & & & & 0.17 & 0.48 & & & \\
\hline P level (P) & 0.19 & 0.7 & & & & 0.27 & 0.96 & & & \\
\hline $\mathrm{V} \times \mathrm{P}$ & 0.39 & 0.59 & & & & 0.55 & 1.06 & & & \\
\hline
\end{tabular}


$\mathrm{V}_{3}$ (JG 315) as the seed size was too small. As the phosphorus levels increased there was a marginal increase in the seed index values also suggesting that phosphorus nutrition essential for increasing the grain weight. Phosphorus plays a key role in pod filling and ultimately enhances the grain yield. This is in agreement with the finding of Gupta et al. (1998).

\subsection{Phosphorus content and uptake by grain}

Significant changes in phosphorus content of grain were noticed due to phosphorus doses in the varieties (Table 5). Except $\mathrm{V}_{2}$ (JG 11), all other varieties maintained significantly higher grain phosphorus content. Although the variety $\mathrm{V}_{2}(\mathrm{JG}$ 11), produced higher yield, it appeared to accumulate higher phosphorus in parts other than the seed. Further, significantly higher phosphorus content was observed for $90 \mathrm{~kg} \mathrm{P}_{2} \mathrm{O}_{5} \mathrm{ha}^{-1}$ irrespective of the variety over lesser $\mathrm{P}$ doses. This corroborates the findings of Ibrahim (1989) and Yahia et al. (1995) reporting that increasing levels of phosphorus significantly increased the plant and seed phosphorus content. Maximum phosphorus content was noticed in $\mathrm{V}_{3}$ (JG 315) at $90 \mathrm{~kg} \mathrm{P}_{2} \mathrm{O}_{5}$ ha $^{-1}$ dose across varieties and phosphorus doses. The highest phosphorus content $(0.23 \%)$ recorded by the variety $\mathrm{V}_{3}$ (JG 315$)$ followed by $\mathrm{V}_{1}$ and $\mathrm{V}_{4}$. The lowest value $(0.20 \%)$ was recorded by the variety $\mathrm{V}_{2}$ (JG11). There was a gradual increase in the phosphorus content of grain from $\mathrm{P}_{1}$ to $\mathrm{P}_{4}$ level in all the varieties. Different levels of phosphorus also affected the grain phosphorus content of rice was reported by Islam et al. (2008). A very good increase in phosphorus content $(0.21-0.27 \%)$ was shown by the variety $\mathrm{V}_{3}(\mathrm{JG} 315)$. This might be due to the ability of the variety to accumulate the phosphorus in the economic parts. Considering the phosphorus content in grains, the variety $\mathrm{V}_{2}$ (JG 11) appeared to be inefficient and the rest of the varieties are efficient genotypes. The increase in phosphorus content was very poor in $\mathrm{V}_{2}(\mathrm{JG} 11)$ and $\mathrm{V}_{4}$ ( JG 218) varieties as they might have accumulated phosphorus in other parts of the plants.

The uptake of phosphorus was significantly different due to phosphorus nutrition. The study could not find any specific relation between variety and phosphorus doses, as the interaction was insignificant. Irrespective of the variety studied, application of $90 \mathrm{~kg} \mathrm{P}_{2} \mathrm{O}_{5}$ ha $^{-1}$ significantly enhanced $\mathrm{P}$ uptake over the other doses and control. This was followed by $60 \mathrm{~kg}$ $\mathrm{P}_{2} \mathrm{O}_{5}$ ha $^{-1}$. This is in agreement with the results obtained by Singh and Singh (2012) in chickpea. The possible reason might

\begin{tabular}{|c|c|c|c|c|c|c|c|c|c|c|}
\hline \multirow[t]{3}{*}{ Variety } & \multicolumn{5}{|c|}{ Number of pod plant ${ }^{-1}$} & \multicolumn{5}{|c|}{ Seed index $(\mathrm{g})$} \\
\hline & \multicolumn{10}{|c|}{ Phosphorus levels $\left(\mathrm{kg} \mathrm{ha}^{-1}\right)$} \\
\hline & 0 & 30 & 60 & 90 & Mean & 0 & 30 & 60 & 90 & Mean \\
\hline JG 16 & 20.00 & 31.67 & 35.67 & 45.67 & 33.25 & 14.06 & 14.10 & 14.60 & 15.15 & 14.48 \\
\hline JG 11 & 22.67 & 33.33 & 49.33 & 61.67 & 41.75 & 17.70 & 17.95 & 18.10 & 18.40 & 18.04 \\
\hline JG 315 & 26.0 & 30.33 & 49.67 & 39.33 & 36.33 & 12.68 & 13.72 & 13.76 & 14.55 & 13.68 \\
\hline JG 218 & 20.33 & 35.67 & 40.67 & 37.67 & 33.58 & 17.34 & 18.15 & 18.16 & 18.29 & 17.98 \\
\hline Mean & 22.25 & 32.75 & 43.83 & 46.08 & & 15.44 & 15.98 & 16.16 & 16.60 & \\
\hline Source & $\mathrm{SEm} \pm$ & $\mathrm{CD}(p=0.05)$ & & & & $\mathrm{SEm} \pm$ & $\mathrm{CD}(p=0.05)$ & & & \\
\hline Variety (V) & 0.77 & 2.71 & & & & 0.20 & 0.72 & & & \\
\hline P level (P) & 0.61 & 1.80 & & & & 0.22 & 0.65 & & & \\
\hline $\mathrm{V} \times \mathrm{P}$ & 1.54 & 3.85 & & & & 0.41 & NA & & & \\
\hline
\end{tabular}

Table 5: Effect of phosphorus levels on phosphorus content and uptake by grain

\begin{tabular}{|c|c|c|c|c|c|c|c|c|c|c|}
\hline \multirow[t]{3}{*}{ Variety } & \multicolumn{5}{|c|}{$\mathrm{P}$ content of grain $(\%)$} & \multicolumn{5}{|c|}{ P uptake by grain $\left(\mathrm{kg} \mathrm{ha}^{-1}\right)$} \\
\hline & \multicolumn{10}{|c|}{ Phosphorus levels $\left(\mathrm{kg} \mathrm{ha}^{-1}\right)$} \\
\hline & 0 & 30 & 60 & 90 & Mean & 0 & 30 & 60 & 90 & Mean \\
\hline JG 16 & 0.20 & 0.21 & 0.22 & 0.24 & 0.22 & 3.29 & 3.77 & 4.70 & 4.86 & 4.15 \\
\hline JG 11 & 0.18 & 0.20 & 0.21 & 0.22 & 0.20 & 3.33 & 3.89 & 4.04 & 5.07 & 4.08 \\
\hline JG 315 & 0.21 & 0.22 & 0.24 & 0.27 & 0.23 & 2.87 & 3.45 & 4.86 & 5.37 & 4.14 \\
\hline JG 218 & 0.20 & 0.21 & 0.22 & 0.23 & 0.22 & 3.21 & 3.41 & 3.88 & 4.29 & 3.70 \\
\hline Mean & 0.20 & 0.21 & 0.22 & 0.24 & & 3.18 & 3.63 & 4.37 & 4.90 & \\
\hline Source & $\operatorname{SEm} \pm$ & $\mathrm{CD}(p=0.05)$ & & & & $\mathrm{SEm} \pm$ & $\mathrm{CD}(p=0.05)$ & & & \\
\hline Variety (V) & 0.004 & 0.014 & & & & 0.24 & NA & & & \\
\hline P level (P) & 0.004 & 0.01 & & & & 0.16 & 0.46 & & & \\
\hline $\mathrm{V} \times \mathrm{P}$ & 0.008 & NA & & & & 0.45 & NA & & & \\
\hline
\end{tabular}


be the adequate and enhanced availability of phosphorus to the plants due to its graded application. This corroborates the findings of Gupta et al. (1992) and Kanwar and Paliyal (2002) who found increase in phosphorus uptake due to phosphorus application. Similar results were reported by Islam et al. (2008). The interaction between varieties and phosphorus levels was found to be non-significant.

\section{Conclusion}

Application of $60 \mathrm{~kg} \mathrm{P}_{2} \mathrm{O}_{5}$ ha $^{-1}$ is sufficient for production of optimum chickpea seed yield. Phosphorus application above $60 \mathrm{~kg} \mathrm{ha}^{-1}$ increased the grain phosphorus content. Based on the phosphorus content in grains, the variety $\mathrm{V}_{2}(\mathrm{JG} 11)$ appeared to be inefficient for phosphorus while the rest were efficient varieties. Hence, the varieties like JG 16, JG 315 and JG 218 may be utilized for chickpea breeding program as they have the capacity to accumulate higher grain phosphorus content to develop P efficient cultivars.

\section{References}

Borgobhain, M., Agarwal, S.K., 1986. Influence of rates and source of phosphorus and irrigation levels on yield and yield attributes of kabuli gram. Indian Journal of Agronomy 31(3), 229-231.

Chauhan, Y.S., Johanson, C., Venkataratnam, N., 1992. Effect of phosphorus deficiency on phenology and yield components of short duration pigeon pea. Tropical Agriculture 69, 235-238.

Dixit, J.P., Dubey, O.P., Soni, N.P., 1993. Effect of sowing date and irrigation on yield and nutrient uptake by chickpea (Cicer arietinum) cultivars under Tawa command area. Indian Journal of Agronomy 38, 227-231.

Gupta, A.K., Kaur, V., Kaur, N., 1998. Appearance of different phosphatase forms and phosphorus partitioning in nodules of chickpea (Cicer arietinum L.) during development. Acta Physiologia Plantarum 20, 369-374.

Idris, M., Mahmood, T., Malik, K.A., 1989. Response of field grown chick pea to phosphorus fertilisation for yield and nitrogen fixation. Plant and Soil 114, 135-138.

Islam, M.A., Islam, M.R., Sarkar, B.S., 2008. Effect of phosphorus on nutrient uptake of Japonica and Indica rice. Journal of Agricultural and Rural Development 6 (1\& 2), 7-12.

Islam, M.J., Peng, S., Visperas, R.M., Bhuiya, M.S., Altafhossain, S.M., Julfiquar, A.W., 2010. Comparative study on yield and yield attributes of hybrid, inbred and NPT rice genotypes in a tropical irrigated ecosystem. Bangladesh Journal of Agricultrual Research 35(2), 343-353.

Jackson, M.L., 1973. Soil chemical analysis. Prentice Hall, India Pvt. Ltd., New Delhi, 498.

Jones, U.S., 1982. Fertilisers and soil fertility (2nd Edn.). Reston
Publication Company, USA, 421.

Kanwar, K., Paliyal, S.S., 2002. Influence of phosphorus management and organic manuring on uptake and yield of chickpea (Cicer arietinum). Annals of Agricultural Research New Series 23(4), 642-645.

Khorgamy, A., Farnia, A., 2009. Effect of phosphorus and zinc fertilisation on yield and yield components of chick pea cultivars. In: African Crop Science Conference Proceedings, Cape Town, 205-208.

Marschner, H., 1995. Mineral nutrition of higher plants. Academic Press Inc., London LTD, 645.

Maiti, R.K., 2012. A novel strategy to improve crop productivity under sustainable agriculture. International Journal of BioResource and Stress Management 3(2), 128-138.

Meena, L., Rang, Singh, T.K., Kumar, R., Kumar, P., 2011. Nutrient uptake, yield and quality of linseed (Linum usitatissimum L.) as affected by fertility levels and seed rates in dry land condition of eastern Uttar Pradesh. International Journal of Bio-Resource and Stress Management 2(1), 083-085.

Mehar, Singh, Rakeshkumar, Singh, R.C., 2000. Agro technology for kabuli chickpea. In: Proceedings of National Symposium on Agronomy: Challenges and Strategies for the Millennium, Gujarat Agriculture University Campus, Junagadh, 128-135.

Patil, R.J., Dudhade, D.O., Patil, J.V., 2002. Response of chickpea to phosphorus under varying moisture regime. Agricultural Science Digest 22 (2), 130-131.

Prasad, J., Sanoria, C.L., 1981. Response of bengal gram to seed and bacterium and phosphorus. Seeds and Farms 7, 31-32.

Singh, D., Singh, H., 2012. Effect of phosphorus and zinc nutrition on yield, nutrient uptake and quality of chickpea. Annals of Plant and Soil Research 14(1), 71-74.

Srinivasarao, Ch., Geneshamurthy, A.N., Ali, M., 2003. Nutritional constraints in pulse production. Bulletin, Indian Institute of Pulses Research, Kanpur, India, 34.

Tomar, S.S., Pathan, M.A., Gupta, K.P., Khandkar, U.R., 1993. Effect of phosphate solubilizing bacteria at different levels of phosphate on black gram (Phaseolus mungo). Indian Journal of Agronomy 38, 131-133.

Williams, J.H., Saxena, N.P., 1991. The use of non-destructive measurement and physiological models of yield determination to investigate factors determining differences in seed yield between genotypes of 'desi' chickpeas (Cicer arietinum). Annals of Applied Biology 119, 105-112.

Yahiya, M., Samiullah, Fatma, A., 1995. Influence of phosphorus on nitrogen fixation in chickpea cultivars. Journal of Plant Nutrition 18, 719-727. 